\title{
High glucose concentrations are associated with symptoms of mild anaemia in Whiskered Terns: consequences for assessing physiological quality in birds
}

\author{
Piotr Minias
}

Received: 4 October 2013/Revised: 15 April 2014/ Accepted: 5 June 2014/Published online: 22 June 2014

(C) The Author(s) 2014. This article is published with open access at Springerlink.com

\begin{abstract}
Although blood concentrations of glucose and haemoglobin are known to correlate with nutritional state of individuals, hyperglycaemic states in vertebrates are often linked to anaemia. A negative relationship between blood concentrations of glucose and haemoglobin was confirmed in a wild population of Whiskered Terns Chlidonias hybrida. Also, terns with higher haemoglobin concentrations initiated laying earlier and had clutches with larger eggs, while blood glucose concentrations of individuals were not associated with the timing of laying and egg size. This implies that blood haemoglobin concentration may be considered a much more robust indicator of physiological quality than glucose concentrations in the Whiskered Tern, and possibly in other waterbirds.
\end{abstract}

Keywords Glucose concentration · Haemoglobin concentration · Hyperglycaemia · Individual quality · Physiological condition · Whiskered Tern

\section{Zusammenfassung}

Hohe Glukose-Blutwerte hängen bei Weißbart-Seeschwalben mit Symptomen leichter Anämie zusammen: Welche Konsequenzen hat dies für die Einschätzung der physiologischen Qualität bei Vögeln?

Obwohl bekannt ist, dass die Glukose- und HämoglobinBlutwerte von Individuen mit deren Ernährungszustand

Communicated by K. C. Klasing.

P. Minias $(\bowtie)$

Department of Teacher Training and Biodiversity Studies,

University of Łódź, Banacha 1/3, 90-237 Łódź, Poland

e-mail: pminias@biol.uni.lodz.pl korrelieren, treten hyperglykämische Zustände bei Vertebraten oft in Verbindung mit Anämie auf. Für Wildpopulationen von Weißbart-Seeschwalben Chlidonias hybrida bestätigte sich ein solch negativer Zusammenhang zwischen den Konzentrationen von Glukose und Hämoglobin im Blut. Außerdem begannen Seeschwalben mit höherem Hämoglobinspiegel früher mit dem Legen und hatten Gelege mit größeren Eiern; der Zeitpunkt der Eiablage und die Eigröße standen jedoch nicht mit der Glukosekonzentration im Blut der Individuen im Zusammenhang. Dies legt nahe, dass bei Weißbart-Seeschwalben - und möglicherweise auch bei anderen Wasservögeln - die Hämoglobinkonzentration im Blut einen weitaus zuverlässigeren Indikator für die physiologische Qualität darstellt als die Glukosekonzentration.

\section{Introduction}

Blood glucose concentration has been widely used to assess nutritional state in different animal species, including birds (e.g. Jenni-Eiermann and Jenni 1994). Although glucose plasma concentrations are often kept within a narrow range, low concentrations of glucose are usually recorded during fasting periods (Jenni-Eiermann and Jenni 1994; Alonso-Alvarez and Ferrer 2001). Similarly to glucose concentration, blood haemoglobin level is commonly used in both field and experimental studies on birds as a proxy of physiological condition. An experimental study by Pyrke and Rollins (2012) demonstrated a positive impact of diet quality on haemoglobin concentrations in nestling Parrot Finches Erythrura trichroa. Similarly, haemoglobin concentrations of Great Tit Parus major nestlings were found to reflect differences in 
trophic conditions between seasons and sites (Bańbura et al. 2007). For these reasons, it can be expected that blood concentrations of glucose and haemoglobin in birds should be positively inter-correlated.

Alternatively, hyperglycaemic states in vertebrates are often linked to anaemia (Winkler et al. 1999), suggesting that blood glucose concentrations should not be considered a robust proxy of individual quality in birds. The mechanism which explains this kind of association is mediated by erythropoietin, a hormone essential for red blood cell production. Erythropoietin is produced by interstitial fibroblasts in the kidney, but oxidative stress associated with hyperglycaemia is known to damage kidneys at several levels, ranging from diabetic nephropathy to chronic kidney disease (Winkler et al. 1999). In such situations, production of erythropoietin may be substantially reduced, which is likely to result in anaemia. It could thus be expected that high glucose concentrations may co-occur with low hemoglobin levels in birds. The aim of this study was to investigate an association between blood concentrations of glucose and hemoglobin in a wild population of Whiskered Terns Chlidonias hybrida and to test whether both parameters can be used as reliable predictors of physiological quality in this species. For that purpose, I analysed whether glucose and hemoglobin concentrations were related to other proxies of individual quality, such as size-corrected body mass, timing of laying and egg volume.

\section{Materials and methods}

The study took place in 2012 in the colony of Whiskered Terns at Jeziorsko reservoir $\left(51^{\circ} 47^{\prime} \mathrm{N}, 18^{\circ} 40^{\prime} \mathrm{E}\right)$, central Poland. Nesting platforms in the colony were built on emergent and floating vegetation, mainly on amphibious bistort Polygonum amphibium. In 2012, 84 active nests were recorded in the colony, all of which were individually marked. The colony was visited 2-3 times a week from the beginning of June, when the first terns started to build nest platforms. The fieldwork lasted until mid-August, when all chicks in the colony had hatched. Laying dates of all clutches in the colony were recorded with an accuracy of 1-2 days. The length (L) and breadth (B) of all the eggs in the colony were measured with plastic callipers to the nearest $0.1 \mathrm{~mm}$. Egg volume (V) was calculated according to the formula of Coulson (1968), where $V=4.866 \times 10^{-4} \times L \times B^{2}$.

During the incubation period, adult birds were captured on nests using a manually triggered spring trap. The capture period lasted from 6 June to 2 August. In total, 21 females and 17 males were captured, all belonging to different social pairs. The following measurements were taken: total head length, bill length, tarsus length (all $\pm 0.1 \mathrm{~mm}$ ), and wing length $( \pm 1 \mathrm{~mm})$. All birds were

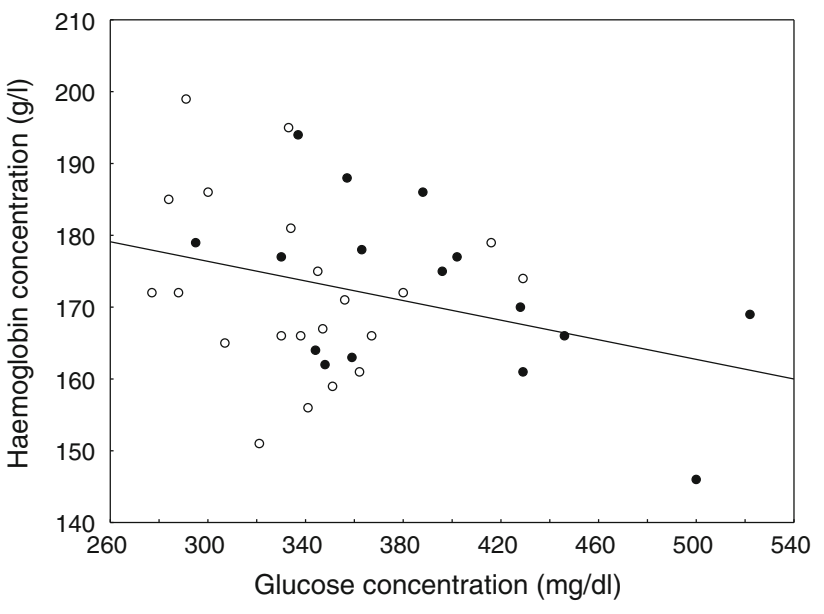

Fig. 1 Relationship between blood concentrations of glucose and haemoglobin in adult Whiskered Terns Chlidonias hybrida (males filled circles, females open circles). The line represents the fitted regression

also weighed to the nearest $1 \mathrm{~g}$. In order to express the overall body size of birds, all univariate measurements except for body mass were reduced to the first principal component (PC1) of a principal component analysis and size-corrected body mass was calculated as residuals of body mass against PC1. All birds were sexed using appropriate discriminant equations developed for the Central European population of the species, which have been demonstrated to yield a classification success rate of $94.6 \%$ (Ledwoń 2011).

Whole blood concentrations of total haemoglobin and glucose were measured in all captured terns. For this purpose, approx. $20 \mu \mathrm{l}$ of blood was collected from the ulnar vein of each bird. The concentration of haemoglobin was determined using a portable $\mathrm{HemoCue} \mathrm{Hb} 201+$ photometer (HemoCue Hb, Ängelholm, Sweden), which uses a modified azide methaemoglobin reaction. Glucose concentrations were measured by a glucose oxidase method implemented in a spectrophotometric CardioChek PA Analyzer 1708 (Polymer Technology Systems, Indianapolis, IN, USA).

General linear models were used to check for the effects of different variables on blood concentrations of haemoglobin and glucose. In the analysis, sex was treated as a fixed factor, whereas size-corrected body mass, timing of laying and mean egg volume were entered as covariates. Stepwise procedures of backward removal were used to select for significant independent variables. Estimate coefficients $(\beta \pm \mathrm{SE})$ were used to assess the character and strength of significant relationships. The proportion of variance explained by particular independent effects was estimated with the partial eta-squared $\eta^{2}$. All values were presented as mean $\pm \mathrm{SE}$. Statistical analyses were performed using Statistica 10.0 (StatSoft). 


\section{Results}

There were significant differences in blood glucose concentration between sexes $\left(F_{1,34}=10.36, P=0.003\right)$, with males having higher glucose concentrations in comparison to females $(390.3 \pm 15.53$ vs. $335.85 \pm 8.95 \mathrm{mg} / \mathrm{dl}$, respectively) (Fig. 1). In contrast, no between-sex variation was found in blood haemoglobin concentrations $(172.19 \pm 3.01$ for males vs. $172.30 \pm 2.78 \mathrm{~g} / 1$ for females; $\left.F_{1,32}=0.12, P=0.73\right)$. After accounting for the effect of $\operatorname{sex}\left(F_{1,34}=10.72, P=0.002\right)$, I found a negative relationship between blood concentrations of haemoglobin and glucose $\left(F_{1,34}=5.18, P=0.029\right)$. The $\beta$ coefficient of the regression line indicated that haemoglobin concentration in adult Whiskered Terns decreased by an average of $6.8 \mathrm{~g} / \mathrm{l}$ per each $100 \mathrm{mg} / \mathrm{dl}$ increase in the concentration of glucose and the effect of blood glucose concentration explained $10.4 \%$ of variation in the haemoglobin level.

There was no relationship between hemoglobin concentration and size-corrected body mass in either sex (males: $F_{1,14}=2.46, P=0.14$; females: $F_{1,19}=0.23$, $P=0.64)$. In contrast, blood haemoglobin concentration of adult terns was significantly associated with the timing of laying $\left(F_{1,34}=13.97, P<0.001\right)$ and mean egg volume $\left(F_{1,34}=5.78, P=0.022\right)$, as individuals with higher haemoglobin levels initiated laying earlier in the season $(\beta=-0.49 \pm 0.13)$ and had clutches with larger eggs ( $\beta=4.64 \pm 1.93$ ) (Fig. 2). The effect of sex was excluded from the model $\left(F_{1,33}=0.14, P=0.71\right)$. Blood glucose concentration was not associated with size-corrected body mass in either males $\left(F_{1,14}=0.21, P=0.65\right)$ or females $\left(F_{1,19}=0.94, P=0.34\right)$. Also, after controlling for the effect of sex, I found no relationship between blood glucose level and the timing of laying $\left(F_{1,34}=0.22, P=0.64\right)$ or the mean egg volume $\left(F_{1,35}=0.35, P=0.56\right)$.

\section{Discussion}

A strong negative correlation between the whole-blood concentrations of haemoglobin and glucose was found in adult Whiskered Terns from a Central European breeding population. This kind of relationship would be expected, assuming that hyperglycaemic states are likely to co-occur with anaemic symptoms in vertebrates. Nevertheless, many more empirical studies are necessary to determine whether negative glucose-haemoglobin correlations may be considered a general pattern in wild populations of birds. I am not aware of any other studies which have empirically evaluated association between blood concentrations of haemoglobin and glucose in wild-living avian species, although several case reports have confirmed concurrent
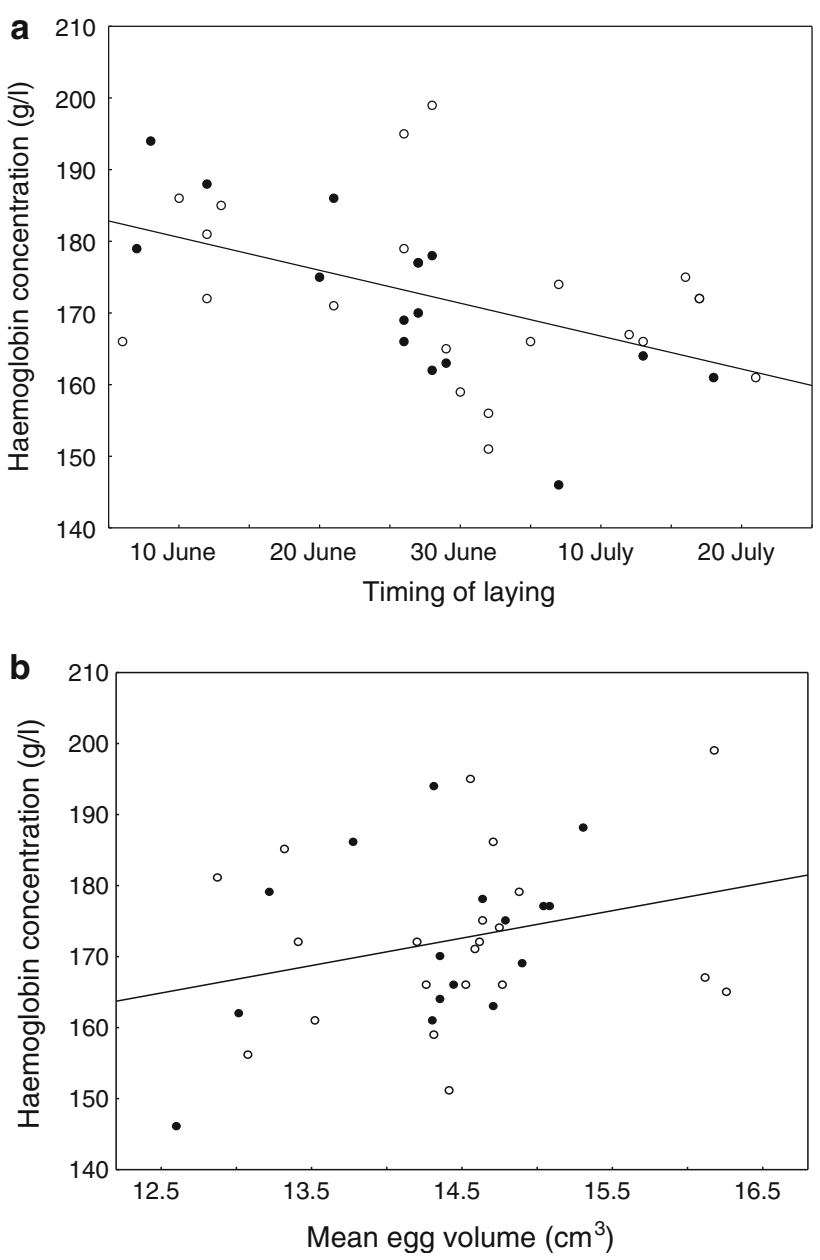

Fig. 2 Relationships of blood haemoglobin concentration with the timing of laying (a) and the mean egg volume (b) in Whiskered Terns at Jeziorsko reservoir in 2012 (males filled circles, females open circles). The lines represent the fitted regressions

symptoms of hyperglycaemia and ineffective haematopoiesis in captive birds (e.g. Pilny and Loung 2005). In general, birds as a class maintain higher glucose concentrations than other vertebrates of similar body mass (Braun and Sweazea 2008). Despite having evolved numerous adaptations to withstand high plasma glucose levels, it seems that, in wild bird populations, a certain fraction of individuals may suffer from hyperglycaemia (Thomas et al. 1975). However, the diagnosis of a hyperglycaemic state in birds is complicated due to the lack of accepted normal blood glucose values and great inter-specific variation in glucose concentrations (Douglass 1981). For all these reasons, the prevalence of individuals with diabetes-associated symptoms, such as anaemia, in wild populations of birds is very difficult to estimate and so far remains unknown.

Since high blood glucose concentrations in Whiskered Terns were associated with relatively low haemoglobin 
levels, resulting in reduced oxygen-carrying capacity of blood, I suggest that glucose levels may be of limited applicability in assessing physiological quality in this species. Low reliability of blood glucose concentration as a proxy of physiological quality in the Whiskered Tern was confirmed by non-significant relationships of this parameter with such quality indices as size-corrected body mass, the timing of laying and mean egg size. In other avian species, the reliability of using blood glucose concentrations as a physiological measure of individual quality has been much debated. A number of studies have demonstrated a decrease in plasma glucose concentrations during food deprivation periods in both wild-living and captive individuals (e.g. Jenni-Eiermann and Jenni 1994; AlonsoAlvarez and Ferrer 2001). Consistently, plasma glucose concentration was identified as the best predictor of body condition among several analysed biochemical parameters in the Great Cormorant Phalacrocorax carbo sinensis nestlings (Minias and Kaczmarek 2013). However, although glucose levels may be indicative for the current nutritional state of an organism, they show rapid changes within a very short time scale (Prinzinger and Misovic 2010). Furthermore, glucose levels are also known to show significant seasonal variation and circadian rhythms (Bairlein 1983; Remage-Healey and Romero 2000), as well as they depend on activity, nervous state and a multitude of other factors (Prinzinger and Misovic 2010). Glucose uptake into tissues is also inhibited by glucocorticoids, hormones that are associated with stress response in birds (Norris 1997). Consequently, as a result of exposure to external stressors, high blood concentrations of glucose can also be recorded in individuals of poor nutritional state.

In contrast, blood haemoglobin concentration was highly correlated with some general indices of individual quality in the Whiskered Tern. Although I found no relationship between haemoglobin level and size-corrected body mass, individuals having higher haemoglobin levels initiated breeding earlier in the season and had clutches with eggs of larger size. This is consistent with the theory that the timing of breeding in migratory birds is phenotypedependent, as individuals of highest quality are able to return the earliest to the breeding grounds, find high-quality mates and initiate breeding (Forstmeier 2002). Also, a positive relationship between blood haemoglobin concentration and mean egg volume indicated that individuals with high haemoglobin levels were either in a better nutritional condition during pre-laying period (females) or were paired to better nourished mates (males). All this seems to confirm that blood haemoglobin concentration may be considered a robust indicator of physiological quality in the Whiskered Tern, and possibly in other waterbirds.
Acknowledgments I thank all the colleagues who participated in the fieldwork. I also thank two anonymous reviewers for helpful comments on the earlier draft of the manuscript. The study was financially supported by a research grant of the Polish Ministry of Science and Higher Education under the 'Iuventus Plus' program (IP2011 036171) and by the Scientific Foundation of the University of Łódź. The research was performed with the permissions of the Bioethical Commission and the General Environmental Protection Directorate in Poland.

Open Access This article is distributed under the terms of the Creative Commons Attribution License which permits any use, distribution, and reproduction in any medium, provided the original author(s) and the source are credited.

\section{References}

Alonso-Alvarez C, Ferrer M (2001) A biochemical study of fasting, subfeeding, and recovery processes in yellow-legged gulls. Physiol Biochem Zool 75:703-713

Bairlein F (1983) Seasonal variations of serum glucose levels in a migratory songbird, Sylvia borin. Comp Biochem Physiol A 76:397-399

Bańbura J, Bańbura M, Kaliński A, Skwarska J, Słomczyński R, Wawrzyniak J, Zieliński P (2007) Habitat and year-to year variation in haemoglobin concentration in nestling blue tits Cyanistes caeruleus. Comp Biochem Physiol A 148:572-577

Braun EJ, Sweazea KL (2008) Glucose regulation in birds. Comp Biochem Physiol B 131:233-241

Coulson JC (1968) Egg size and shape in Kittiwake (Rissa tridactyla) and their use in estimating age composition of populations. Proc Zool Soc Lond B 140:211-227

Douglass EM (1981) Diabetes mellitus in a toco toucan. Mod Vet Pract 62:293-295

Forstmeier W (2002) Benefits of early arrival at breeding grounds vary between males. J Anim Ecol 71:1-9

Jenni-Eiermann S, Jenni L (1994) Plasma metabolite levels predict individual body-mass changes in a small long-distance migrant, the Garden Warbler. Auk 111:886-897

Ledwoń M (2011) Sexual size dimorphism, assortative mating and sex identification in the Whiskered Tern Chlidonias hybrida. Ardea 99:191-198

Minias P, Kaczmarek K (2013) Concentrations of plasma metabolites as predictors of nestling condition in the Great Cormorant (Phalacrocorax carbo sinensis). Ornis Fenn 90:142-150

Norris DO (1997) Secretion and action of glucocorticoids. Vertebrate endocrinology. Academic, Boston, pp 308-311

Pilny AA, Loung R (2005) Diabetes mellitus in a chestnut-fronted macaw (Ara severa). J Avian Med Surg 19:297-302

Prinzinger R, Misovic A (2010) Age-correlation of blood values in the Rock Pigeon (Columba livia). Comp Biochem Physiol A 156:351-356

Pyrke SR, Rollins LA (2012) Mothers adjust offspring sex to match the quality of the rearing environment. Proc R Soc Lond B 279:4051-4057

Remage-Healey L, Romero LM (2000) Daily and seasonal variation in response to stress in captive starlings (Sturnus vulgaris): glucose. Gen Comp Endocr 119:60-68

Thomas VG, Lumsden HG, Price DH (1975) Aspects of winter metabolism of ruffed grouse (Bonasa umbellus) with special reference to energy reserves. Can J Zool 53:434-440

Winkler AS, Marsden J, Chaudhuri KR, Hambley H, Watkins PJ (1999) Erythropoietin depletion and anaemia in diabetes mellitus. Diabetic Med 16:813-819 